\title{
USING $\gamma$ RAY-INDUCED SILVER NANOPARTICLES ON CONTROL OF CLUBROOT DISEASE OF CHINESE CABBAGE CAUSED BY PLASMODIOPHORA BRASSICAE
}

\author{
Le Thi Anh $\mathrm{Tu}^{1, \bowtie}$, Pham Thi Le $\mathrm{Ha}^{2}$ \\ ${ }^{1}$ Da Lat University, Lam Dong, Vietnam \\ ${ }^{2}$ The Nuclear Research Institute of Da Lat, Lam Dong, Vietnam \\ ${ }^{\square}$ To whom correspondence should be addressed. E-mail: tulta@dlu.edu.vn
}

Received: 14.02 .2017

Accepted: 20.10.2017

\section{SUMMARY}

\begin{abstract}
Plasmodiophora brassicae- the casual cause of clubroot disease of plants belonging to the family Brassicaceae. This soil-borne fungus infects plants through root hairs. Diseased roots become swollen and deformed. Thus, it's difficult for plants to absorb water and nutrients. There are some methods used to control this disease including soil fumigation, soil $\mathrm{pH}$ control, fungicides, surfactants applications, calcium supplementation, but the results are still restricted. Plasmodiophora brassicae was isolated, identified and artificial inoculated on the Chinese cabbage. The rate of root hair infection and gall formation depended on the spore density and growth media. The increase of the pathogen density lead to the increase of disease symptoms. Silver nanoparticles (SNPs) are widely used as an agent for antifungal treatment. The antimicrobial activity of the nanoparticles varies on the size, shape, and the function of the surface area. The $\gamma$ - irradiation method to synthesize SNPs is known as a method that can be controlled the out coming sizes, shapes and size distribution of particles. The average diameter of silver nanoparticles in this research was $9.5 \mathrm{~nm}$. In the liquid culture and soil, SNPs exhibited a controlling effect on P. brassicae. The fungicide activity depended on the SNP concentrations and the medium; no disease symptoms were found at the SNP concentrations of $1.06 \mathrm{ppm}$ in the liquid culture, and 10 and $20 \mathrm{ppm}$ in soil. Results of the study also showed that the biomass and height of infected plants were much lower than those of the healthy plants. Comparing to the plants that were grown in the sterilized soil, there was not significant difference between the biomass and the height of plants exposed to pathogen and treated with SNPs.
\end{abstract}

Keywords: Biomass, clubroot disease, Chinese cabbage, fungicidal, height, Plasmodiophora brassicae, silver nanoparticles

\section{INTRODUCTION}

Clubroot of cabbage, caused by Plasmodiophora brassicae, is an important disease of crucifers worldwide (Asano et al., 2000; Dixon, 2009). P. brassicae is a soil-born obligate parasite. The formation of club-shaped tumor on both tap and lateral roots associated with the wilting is common symptom of the clubroot disease. In Da Lat, a large vegetable production area of Vietnam, this disease has established on crucifers whole year (Dixon, 2009). Currently, soil fumigation, application of fungicides, surfactants, supplemental calcium, liming to increase soil $\mathrm{pH}$ are methods used to control this disease, however the results are still restricted (Tremblay et al., 1999; Donald et al., 2002; Taylor et al., 2002).
Silver nanoparticles (SNPs) are among the most thoroughly explored and extensively investigated antimicrobial agents (Elechiguerra et al., 2005; Fröhlich, Fröhlich, 2016). Silver can attack a broad range of biological process in microorganisms ( Gajbhiye et al., 2009; Jiang et al., 2012; Fröhlich, Fröhlich, 2016;). While micro-molar concentrations are sufficient to kill bacteria in water, these doses have no harmful effects on human. The biocidal properties of SNPs result from the alteration of proteins and/or structural and metabolic disruption (Maillard, Denyer, 2006; Silver et al., 2006). Some mechanism have been reported including direct membrane interaction (Jo et al., 2009; Kim et al., 2012; Fröhlich, Fröhlich, 2016), delivering more ionic silver to small surface (Maillard, Denyer, 2006; Jo et al., 2009), the loss of membrane integrity due 
to increase the production of reactive oxygen species (McShan et al., 2014). Their high antifungal properties lead to the potential applications is in management of various plant diseases (Stampoulis et al., 2009; Kim et al., 2012). However, no study on the applicability of SNPs for controlling clubroot diseases on crucifer has been reported.

The antimicrobial activity of the nanoparticles varies on the size, shape, and the function of the surface area (Stampoulis et al., 2009). Therefore, the preparation of uniform nanosized SNPs with specific requirements in term of size, shape and physical and chemical properties are attracting more interest. SNPs can be prepared with a variety of synthetic methods such as mechanical grinding, coprecipitation, spraying, and electrolysis sol-gel manufacture. Among them, the $\gamma$ - irradiation method can control the out coming sizes, shapes and size distribution of particles (Kumar et al., 2005; Li et al., 2007). The particles may also be prepared at the room temperature by using this method. This article presents the possible of using SNPs that were prepared by $\gamma$ irradiation in order to control of clubroot disease of cabbage caused by $P$. brassicae.

\section{MATERIALS AND METHODS}

\section{Materials}

Silver nanoparticles were obtained from The Nuclear Research Institute of Da Lat, Lam Dong province, Viet Nam. Seeds of cabbage (Brassica oleracea var. capitate) were obtained from Hoasen, Inc. (DL, Viet Nam).

\section{Plasmodiophora brassicae resting spore preparation}

Resting spore suspension of $P$. brassicae was isolated from clubroot galls of the heavily infected plants on property in Da Lat, Lam Dong province, Viet Nam. These spores were extracted and purified by gradient centrifugation as described by Suzuki et al., (1992). Spore suspension was diluted with sterilized distilled water to give a final concentration of $10^{6}$ spores per $\mathrm{mL}$ by using a haemocytometer. Cabbage plants were artificially inoculated with $P$. Brassicae spores.

\section{Infected root hair count and diseases assessment}

The plants were removed carefully and their root were washed in water to remove soil. The root hair infection with the $P$. brassicae was determined by the method described by Takahashi et al. (1991). The number of plants with visible clubs was counted. The disease severity index was calculated using the formula as follows:

0: none, $1:<33.33 \%, 2: 33.33-66.66 \%, 3:>66 \%$

Didease index $=100 \times(B+2 C+3 D) / 4(A+B+C+D)$

Where $A, B, C$, and $D$ represent the number of plants rated at $0,1,2$, and 3 , respectively.

The growth was determined by measuring the height and the biomas of plants. The height was measured from the ground to the top of the plants. The plants were dried for at least $48 \mathrm{~h}$ at $80^{\circ} \mathrm{C}$, then cooled in a desicator jar and determine the dry weight.

\section{Experiment design}

To study effects of the SNPs on P. brassicae, the experiments were carried out in the liquid culture and raised field beds.

\section{Liquid culture inoculation}

The plants (B. oleracea) were grown in liquid cultures with the method of Hanna Friberg (Friberg et al., 2005). Seeds of cabbage were laid on moist wool fibers packed in holes $(2 \mathrm{~cm}$ diameter $)$ which were bored on a Styrofoam plate ( $7 \mathrm{~mm}$ thick). The plate was floated on water in a $1 \mathrm{~L}$ water tank, which was bubbled by a small electric air pump to supply the water with oxygen. The tanks were kept at $25^{\circ} \mathrm{C}$ and at $18^{\circ} \mathrm{C}$ under day time and night time respectively, with a $16 \mathrm{~h}$ photoperiod under illumination of 15,000 lux in the day time. Ten Chinese cabbage seedlings were grown per test. All treatments were triplicated.

\section{Soil inoculation}

The 15 day seedlings were grown in the raised beds used the local soil with $\mathrm{pH} 6 \pm 0.5$. The experiments were carried out in the green house with natural light without supplemental lighting (photoperiod $10-14 \mathrm{~h}$ ) at $23.5 \pm 5^{\circ} \mathrm{C}$. Water and nutrients (N, 20\%; P, 12\%; K, 16\%) were applied as required. Ten Chinese cabbage seedlings were grown per treatment. Each treatment had triplicated.

\section{The effect of varying density of spore suspension on root hair infection and club formation}

The effect of varying density of spore suspense on root hair infection was studied in the nutrient solution and in soil. At the day of $15^{\text {th }}, P$. brassicae resting spores were added from the stock to achieve 
final treatment concentrations of $10^{2}, 10^{3}, 10^{4}, 10^{5}$, $10^{6}$, and $10^{7}$ spores $/ \mathrm{mL}$ in the nutrient solution and $10^{2}, 10^{3}, 10^{4}, 10^{5}, 10^{6}$, and $10^{7}$ spores/g dry soil in raise bed. For both experiments in nutrient solution and in the soil, the root-hair infection and club formation were observed.

\section{The effect of SNPS on P. brassicae}

The 15 day seedling was treated with SNPs and $P$. brassicae resting spores in nutrient solution and in soil. The spore concentraion was adjusted to $10^{6}$ spores $/ \mathrm{mL}$ in the nutrient solution. The SNPs were added to achieved final treatment concentrations of $0.3,1.06$ and $3.08 \mathrm{ppm}$ in the nutrient solution. Two controls were included with each experiment: the control number 1: non infected with $P$. brassicae, the control number 2: infected with $P$. brassicae without SNPs. The root hair infection, height of plants, and club formation were investigated.

The similar experiments were conducted to test the effect of SNPs on P. brassicae with seedlings growth in contaminated soil with concentration of $10^{6}$ spores/g dry soil. The 15 day seedlings were dipped in to 5, 10, and $20 \mathrm{ppm}$ the SNPs solutions before being transplanted into the raised beds. Control plants were dipped into water. During the time of experiment, the day wilt symptom of plants was observed. Biomass and the disease severity index were studied after 90 days

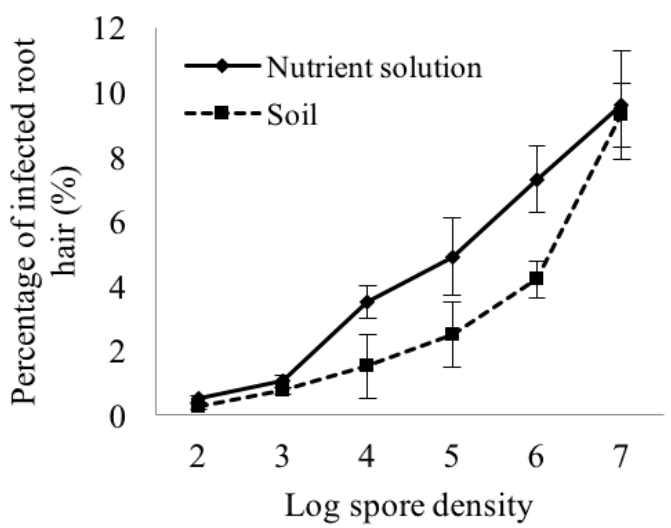

Figure 2. Effect of spore density on the roothair infection.

Increasing club formation with increasing the spore density was aslo observed at the seedlings after 22 days growing in liquid culture and soil (Figure 1 and Figure 2). For both growth media, the club formation varied with density. The small white clubs with the diameter of $1.5-3 \mathrm{~mm}$ formed on the roots

\section{Statistics}

Analysis of variance (ANOVA) and t test at 5\% significance level were performed for data analysis. ANOVA, $F$ test and $t$ test were used together to analyze the difference in the root-hair infection, club formation, height, and biomas by different experimental conditions. The Minitab Program was used for statistical analysis.

\section{RESULTS}

\section{Dose effect on root hair infection and club formation}

To study the relation of spore density to the root hair infection, 15 day Chinese cabbage seedlings were grown on contaminated liquid culture $\left(10^{2}, 10^{3}\right.$, $10^{4}, 10^{5}, 10^{6}$, and $10^{7}$ spores $/ \mathrm{mL}$ ) (Figure 1,2 ) and the soil that was iniculated with $10^{2}, 10^{3}, 10^{4}, 10^{5}$, $10^{6}$, and $10^{7}$ spores/g dry soil (Figure 1,2 ). After 10 days, no incidence of root hair infection was found at the experiments of $10^{2}$ spores $/ \mathrm{mL}$ and $10^{2}$ spores $/ \mathrm{g}$ dry soil. The root hair infection genertally incresed with the increasing spore density. This trend was observed for both cabbages growth in liquid culture and soil. When comparing the effects of growth media for cultivation on the root hair infection, liquid culture resulted in a greater infection at all spore density $(\mathrm{p}<0.005)$.

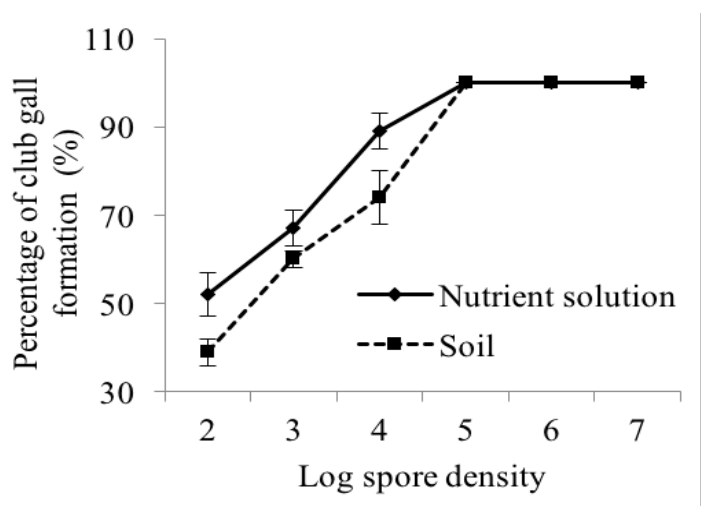

Figure 3. Effect of spore density on the clubroot gall

of plants. However, the clubs were observed even at the lowest spore density $-10^{2}$ spores $/ \mathrm{mL}$ and $10^{2}$ spores/g dry soil. The clubroot symptoms on Chinese cabbage show in Figure 3. 100\% plants growth in $10^{4}$ spores $/ \mathrm{mL}$ and more had visible clubs in the liquid culture while in the soil, all plants were 
clubbed when spore density was $10^{5}$ spores/g dry soil. A similar trend with root hair infection was found in club formation - the plant desease symptom was observed sooner in experiments in liquid culture comparing with soil.

\section{The effect of SNPs on Plasmodiophora brassicae}

\section{Liquid culture inoculation}

The effects of SNPs on root hair infection, club formation, and height of cabbage in contaminated cultures were studied. Cabbage seedlings grew in nutrient solution mixed with $10^{6} / \mathrm{mL}$ resting spores of $P$. brassicae and SNPs at the concentrations of $0.33,1$ and $3 \mathrm{ppm}$ (Figure 4). No root hair infection was found at the first 5 days after inoculation. The symptom development was obtained at $7^{\text {th }}$ day and gradually increased when the plants lasted longer. The similar trend was found in the treatment of $0.3 \mathrm{ppm}$, with the exception that the symptom was observed at the $11^{\text {th }}$ day. At the treatment of 1.06 and $3.08 \mathrm{ppm}$ SNPs, in all cases, $100 \%$ inhibition of root hair infection was recored.

The results of club formation are shown in Figure 5. There are no infected plants observed in the control path after infected. Plants that exposed to pathogens without SNPs lot infected 100\% (the control 2) and the height of plants was lower than that in the control 1. More than 70 percent of plants treated with $0.3 \mathrm{ppm}$ was found infected with disease. No plant treated with SNPs at the concentrations of $1 \mathrm{ppm}$ and $3 \mathrm{ppm}$ had club formation. Height of plants was also measured. While the height of plants that incubated with inoculum is lower than that of the control plants. The height of the control plants is statically greater than plants that treated with SNPs of 0.33 ppm. Meanwhile the height of plants exposed to 1 ppm and $3 \mathrm{ppm}$ of SNPs are not statistically different compared to the control 1 .

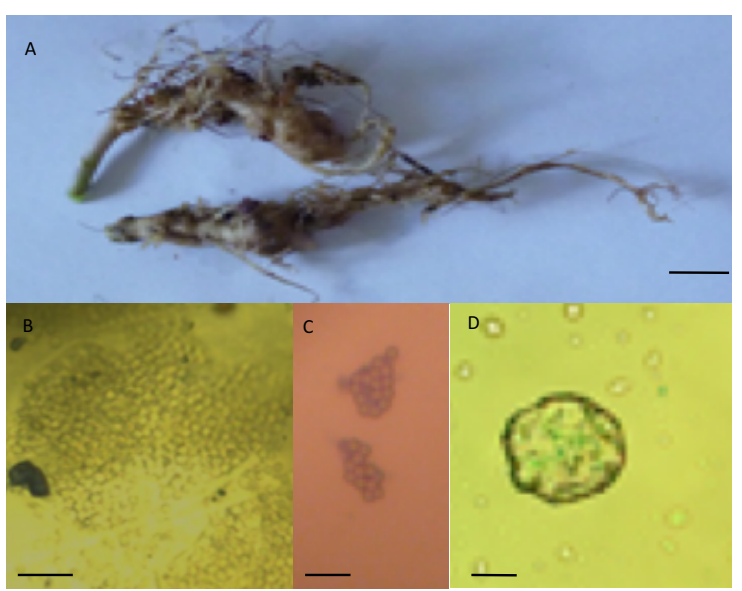

Figure 3. Clubroot symptoms on Chinese cabbage plants: $(A)$ Galls produced on the root (Scale bar $=1 \mathrm{~cm})$; $(B)$ Resting spores on the plant cells (scale bar $=20 \mu \mathrm{m}) ;(C)$ clusters of resting spores (scale bar $=10 \mu \mathrm{m})$; $(\mathrm{D})$ Resting spore (scale bar $=1 \mu \mathrm{m})$.

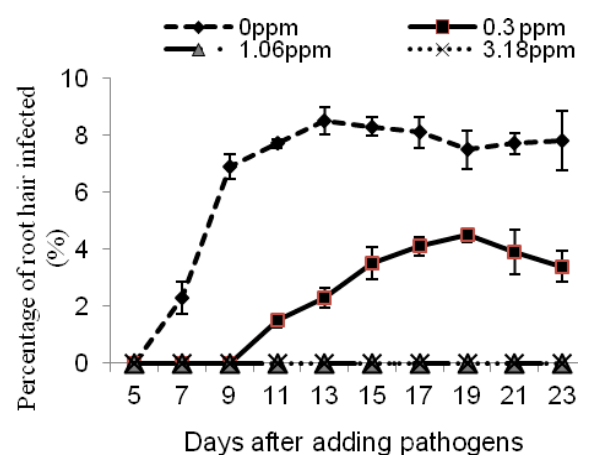

Figure 4. Effect of silver nanoparticles on roothair infection.

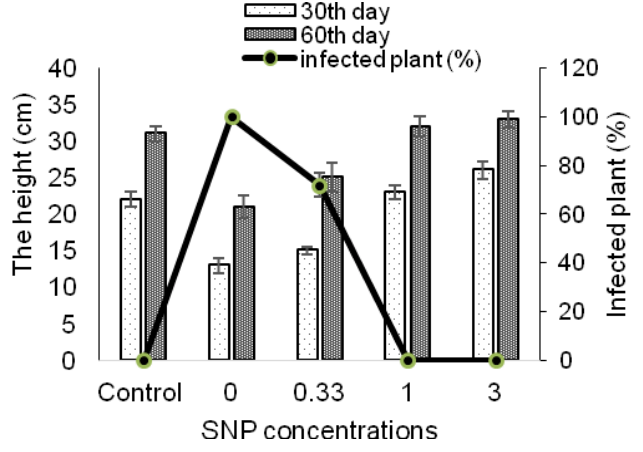

Figure 5. Effect of silver nanoparticle concentrations the height and infected plants growth in soil. 


\section{Clubroot disease control of SNPSSNPsin raised beds}

The day wilt of plants during the hot periods of the day was observed. The plants of the control 1 were grown in the contaminated soil strongly wilted. Lightly wilt symptoms were observed at SNP concentration of $5 \mathrm{ppm}$. No plants was found midday wilting symptoms at two dosage rates of 10 and 20 ppm of treatments (Figure 6 and Table 1).

The results of club formation are shown in table 1. The similar trend with the plants cultivated in liquid culture was observed. No infection could be detected in the growth of cabbage in the sterilized soil at the $60^{\text {th }}$ day after infected. Whole plants exposed to the pathogens infected $100 \%$ and the height of plants was lowest. Plants treated with 5 ppm of SNPs were found infection $(67 \pm 2.15 \%)$. Plants treated with SNPs at the concentrations of 10 ppm and $20 \mathrm{ppm}$ were observed healthy with no club formation. The height of plants in the control 1 is statically greater than plants that treated with SNPs of 5 ppm SNPs. Comparing the average height between the treatments, the plants treated with SNPs were significant taller than the plants only inoculated with fungi spores without treated SNPs. There was no statistical different between the plants growth in the sterilized soil and the plants treated with 10 and 20 ppm SNPs.

Table 1. Effect of silver nanoparticle (SNPs) concentration on day wilting of plant growth in soil.

\begin{tabular}{lllll}
\hline SNPs (ppm) & 0 & 5 & 10 & 20 \\
\hline Day wilting symptom & +++ & + & - & - \\
\hline
\end{tabular}

Note: Strongly wilted: $+++\quad$ Wilted: ++ ; Lightly wilted: +

Non wilted: -

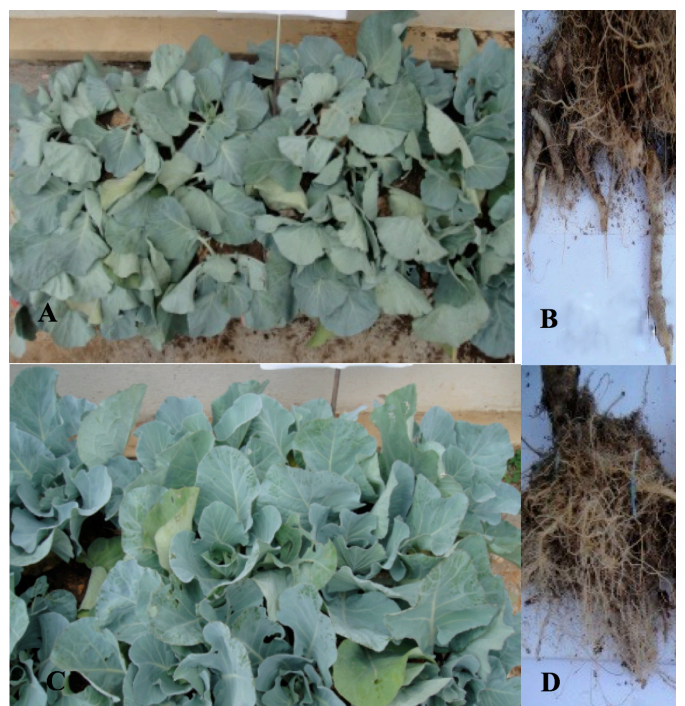

Figure 6. Clubroot symptoms on Chinese Cabbage plants: (A) Infected control plant showing wilt; (B) Galls of infected control plants; (C) Non-day wilting of the plants treat with 10 ppm SNPs; (D) Healthy roots of the plants treat with $10 \mathrm{ppm}$ SNPs.

The results of plant biomass were showed in figure 7 . The biomass of the plants that were grown in the contaminated soil was lower than other treatments. As expected, the increase of biomass of plants was associated with the disease index. The

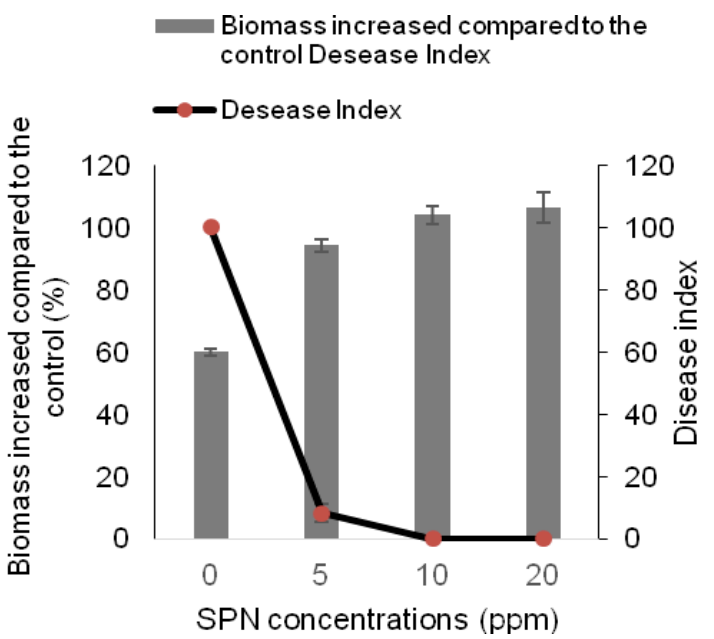

Figure 7. Effect of silver nanoparticle concentration on the biomass and disease index of plants growtzh in soil

plants that had the visible clubs were smaller than others that were not infected. Some of them die with the rot root. The biomass of the plants that only exposed to $P$. brassicae was significantly lower than other treatments. Compared to the control 1 (plants 
were not inoculated with pathogens), the biomass of plants treated with 5 ppm SNPs slightly lower. There was no significant difference between the biomass of the plants that were not inoculated with pathogens and the plants that were grown in the treatments of 10 and $20 \mathrm{ppm}$. No clubbed appearence was found at all incubation periods at these two dosage rate. On the basis of the activity exhibited, the disease index was evaluated. The disease index decreased with the increasing SNP concentrations.
The SNPs exhibited activity against clubroot disease. More than $85 \%$ inhibition in clubroot formation was observed using the treatment concentration of $5 \mathrm{ppm}$ (data not shown). The galls were white comparing being grey in the controls. The club diameter of plants treated 5 ppm SNPs was $1.5 \pm 0.5 \mathrm{~mm}$ comparing with the diameter of $5 \pm 1 \mathrm{~mm}$ at the controls. Fungicidal activity increased when the concentration of SNPs increased, giving complete control of $P$. brassicae at 10 and $20 \mathrm{ppm}$.

Table 2. Effect of silver nanoparticle concentration on the height of plant and clubbing ratio of roots growth in liquid culture.

\begin{tabular}{llllll}
\hline Sample & \multicolumn{5}{c}{ Concentration of silver nanoparticles, ppm } \\
\hline & Control 1 $^{\mathbf{a}}$ & Control 2 $^{\mathbf{b}}$ & $\mathbf{5}$ & $\mathbf{1 0}$ & $\mathbf{2 0}$ \\
\hline Height, $\mathrm{mm}\left(30^{\text {th }}\right.$ day $)$ & $24.1 \pm 2.13$ & $15.5 \pm 1.05$ & $20.3 \pm 1.78$ & $24.5 \pm 2.03$ & $28.8 \pm 1.06$ \\
Height, $\mathrm{mm}\left(60^{\text {th }}\right.$ day) & $32.5 \pm 1.03$ & $20.5 \pm 1.74$ & $26.2 \pm 1.09$ & $32.0 \pm 1.12$ & $35.4 \pm 1.85$ \\
Infected plant, $\%$ & 0 & 100 & $67.1 \pm 2.15$ & 0 & 0 \\
\hline
\end{tabular}

Note: ${ }^{a}$ : control 1: non infected with Plasmodiophora brassicae; ${ }^{b}$ : control 2: infected but not inoculation with SNPs (Oppm of SNPS).

\section{DISCUSSION}

The resting spores were inoculated with seedlings in liquid culture and in soil. While none plants on the control bed was infected, gall clubs were found at all tested plants. This indicated that the spores isolated were the resting spores of $P$. brassicae and artificial inoculation can be carried out in cabbage plants that were grown in soil and nutrient solution (Figure 1 and Figure 2). The technique to produce inoculum and produce disease symptoms under artificial conditions will allow further study of all aspects of the disease caused by this pathogen. Mugnier (1987) reported that in a solid medium, there was root hair infection but not gall formation; in a liquid medium, no root hair infection was observed but gall formation. Graveland et al., (1992) stated that small galls were found but no resting spore was observed in the root hair. In this study, resting spores, root hair infection and clubroot formation were found in both soil and liquid culture. This result might be explained by the different in the element of growth medium. The disease symptom depended on the inoculum density. These results agree with the previous reports that the number of infected root hair increased concomitantly with spore density ( Samuel, Garrett, 1945; Macfarlane, 1958).

As expected, Chinese cabbage plants were grown in the control lot did not develop the symptoms. The plants grew taller than those exposed to pathogens and yielded the good biomass. The seedling exposed to the pathogen had impact on the plant biomass and diseases symptom. Even it was reported that the clubbed roots can arise from a single resting spore in rape (Buczacki et al., 1975), in this study, the root hair infection was only found when the spore densities exceeded $10^{3}$ spores/g dry soil and $10^{3}$ spores $/ \mathrm{mL}$. This data agreed with the results of Donald et al., (2002). The club formation occurred even at the lower spore density of $10^{2}$ spores/g dry soil and $10^{2}$ spores $/ \mathrm{mL}$.

The growth media affected the rate of root hair infection and then the rate of club formation. In the previous work with $P$. brassicae, the primary zoospores move to the host cells between the soil particles through the continuous moisture film (Dixon, 2009). Murakami et al., (2003) reported that physical properties of soil including soil compaction affect the rate of infection. More compacted soil reduced the movement of spores into the subsoil. In the same $\mathrm{pH}$ environment, the movement of the primary zoospores with two flagella may be easier in liquid culture than in the soil particle; therefore, percentage of infected root hair of seedlings growth on the liquid culture was higher than that growth on the soil start at the spore density of $10^{4} \mathrm{spore} / \mathrm{g}$ dry. 
Management of fungal diseases on crops and plants is economically important. The current studies reported that SNPs were very effective for reducing plant diseases caused by spore producing phytopathogenic fungi (Kim et al., 2012; Chmielowiec-Korzeniowska et al., 2013; Pulit et al., 2013). Resting spores of $P$. brassicae are the source of inoculum in infections of clubroot. Results in this study showed that SNPs have significant antifungal activity in both in vitro assays and in plant inoculation experiments on $P$. brassicae. The magnitude of symptoms depended on the SNP concentrations. The fungicidal activity increases with the increasing of SNP concentrations. These results agree with studies on the toxicity of SNPs on other fungi reported of the growth media (Sarkar et al., 2007; Nasrollahi et al., 2009).

At low concentrations of SNPs $(0.3 \mathrm{ppm}$ in liquid culture and $5 \mathrm{ppm}$ in soil), the pathogen was partly inhibited. The plants exhibited delayed development of disease symptoms after inoculation with spore suspensions of $P$. brassicae, which caused of the club root disease of cabbage ( $11^{\text {th }}$ day) comparing with the $7^{\text {th }}$ day of the control. No diseases symptom was found at higher exposed SNPs concentration for 23 days. The result that the disease index in experiments exposed to SNPs in soil was significant less than that in the control also supports the conclusion that SNPs inhibits the club root pathogens. No significant inhibition on biomass and the height at SNPs concentrations of 10 and 20 ppm comparing to the plants growth in the pasteurized soil. Yin et al., (2012) observed that leaf and root biomass of $C$. luria, Panicum virgatum increased response to SNPs while several taxa showed the decreasing in the biomass after expose to SNPs. Zea et al., (2012) stated that small concentration of SNPs enhanced the growth of bean and corn. This controversy can be explained that the impacts of SNPs on the plants growth depend on the plants species and SNPs size and concentrations.

Under high humidity and warm temperature, resting spores that attached to the plant surface germinate and form germ tubes (Macfarlane, 1970; Siemens et al., 2009; Sharma et al., 2011; Gossen et $a l ., 2013,2012)$. This initiated the disease infection. When SNPs and P. brassicae were applied to the nutrient solution in the same time, the particles may cover the surface of spores and inhibited the germination. Additionally, the direct contact between SNPs and spores interfere the attachment of freely swimming primary zoospores liberated from the resting spores on the root surface. Murakami et al., (2002, 2001, 2000) reported that the reduction of number of resting spores in soil associated with the reduction of disease development.

SNPs might direct attach to and penetrate to the cell membrane to kill the spores. In this present work, it is not possible to determine whether SNPs penetrate into microbial cell membranes and kill the spores. Another hypothesis is the SNPs attached on the surface of resting spores and inhibited the germination. At low concentrations of SNPs (0.3 ppm in liquid culture and 5ppm in soil), the pathogen was partly inhibited. This may have related to the ratio between nano particles and spores. Some of spores may not contact with the SNPs and keep germinating while others contact to the particles and lead to be lethal or unable germinating.

In conclusion, the results presented here demonstrated that the club root disease could be artificial infected both in the liquid culture and soil. The disease symptom depended on the inoculum density and the media. SNPs inhibited the development of $P$. brassicae that causing the club root disease. The antifungal activities depended on the SNP concentration and the growth media. The SNPs did not show effect on the plant growth including biomass and height. The hypothesis of SNPs germination inhibition of $P$. brassicae resting spores should be tested further before any general conclusions can be drawn.

Acknowledgements: We thank Nguyen Tan Man for providing SNPS. A part of this work was supported by grant of The Nuclear Research Institute of Da Lat, Lam Dong province, Viet Nam.

\section{REFERENCES}

Asano T, Kageyama K, Hyakumachi M (2000) Germination of surface-disinfected resting spores of Plasmodiophora brassicae and their root hair infection in turnip hairy roots. Mycoscience 41: 49-54.

Buczacki ST, Toxopeus H, Mattusch P, Johnston TD, Dixon GR, Hobolth L A (1975) Study of physiologic specialization in Plasmodiophora brassicae: Proposals for attempted rationalization through an international approach. Trans Br Mycol Soc 65: 295-303.

Chmielowiec-Korzeniowska A, Krzosek L, Tymczyna L, Pyrz M, Drabik A (2013) Bactericidal, fungicidal and 
virucidal properties of nanosilver. Mode of action and potential application. A review. Ann Univ Mariae CurieSklodowska 31: 1-11.

Dixon GR (2009) The occurrence and economic impact of plasmodiophora brassicae and clubroot disease. J Plant Growth Regul 28: 194-202.

Donald EC, Lawrence JM, Porter IJ (2002) Evaluation of a fluorescent staining technique as an indicator of pathogenicity of resting spores of Plasmodiophora brassicae. Australas Plant Pathol 31: 373-379.

Elechiguerra JL, Burt JL, Morones JR, Camacho-Bragado A, Gao X, Lara HH, Yacaman MJ (2005) Interaction of silver nanoparticles with HIV-1. J Nanobiotechnology 3: 6.

Friberg H, Lagerlof J, Ramert B (2005) Germination of Plasmodiophora brassicae resting spores stimulated by a non-host plant. Eur J Plant Pathol 113: 275-281.

Fröhlich EE, Fröhlich E (2016) Cytotoxicity of nanoparticles contained in food on intestinal cells and the gut microbiota. Int J Mol Sci 17: 509.

Gajbhiye M, Kesharwani J, Ingle A, Gade A, Rai M (2009) Fungus-mediated synthesis of silver nanoparticles and their activity against pathogenic fungi in combination with fluconazole. Nanomedicine 5: 382-386.

Gossen BD, Kasinathan H, Cao T, Manolii VP, Strelkov SE, Hwang SF, McDonald MR (2013) Interaction of $\mathrm{pH}$ and temperature affect infection and symptom development of Plasmodiophora brassicae in canola. Can J Plant Pathol 35: 294-303.

Gossen BD, Adhikari KKC, Mcdonald MR (2012) Effects of temperature on infection and subsequent development of clubroot under controlled conditions. Plant Pathol 61: 593-599.

Graveland R, Dale P, Mithen R (1992) Gall development in hairy root cultures infected with Plasmodiophora brassicae. Mycol Res 96: 225-228.

Jiang HS, Li M, Chang FY, Li W, Yin LY (2012) Physiological analysis of silver nanoparticles and AgNO3 toxicity to Spirodela polyrhiza. Environ Toxicol Chem 31: $1880-1886$

Jo YK, Kim BH, Jung G (2009) Antifungal activity of silver ions and nanoparticles on phytopathogenic fungi. Plant Dis 93: 1037-1043.

Kim SW, Jung JH, Lamsal K, Kim YS, Min JS, Lee YS (2012) Antifungal effects of silver nanoparticles (AgNPs) against various plant pathogenic fungi. Mycobiology 40: $53-58$.

Kumar M, Varshney L, Francis S (2005) Radiolytic formation of Ag clusters in aqueous polyvinyl alcohol solution and hydrogel matrix. Radiat Phys Chem 73: 21-27.
Li T, Park HG, Choi SH (2007) Gamma-irradiationinduced preparation of $\mathrm{Ag}$ and $\mathrm{Au}$ nanoparticles and their characterizations. Mater Chem Phys 105: 325-330.

Macfarlane I (1958) A solution-culture technique for obtaining root-hair, or primary, infection by Plasmodiophora brassicae. J Gen Microbiol 18: 720-32. Macfarlane I (1970) Germination of resting spores of Plasmodiophora brassicae. Trans Br Mycol Soc 55: 97-112.

Maillard J, Denyer SP (2006) Focus on silver. World Wide Wounds.

McShan D, Ray PC, Yu H (2014) Molecular toxicity mechanism of nanosilver. J Food Drug Anal 22: 116-127.

Mugnier J (1987) Infection by Polymyxa betae and Plasmodiophora brassicae of roots containing rootinducing transferred DNA of Agrobacterium rhizogenes. Phytopathology 77: 539-542.

Murakami H, Tsushima S, Kuroyanagi Y, Shishido Y (2002) Reduction of resting spore density of Plasmodiophora brassicae and clubroot disease severity by liming. Soil Sci Plant Nutr 48: 685-691.

Murakami H, Tsushima S, Shishido Y (2000) Soil suppressiveness to clubroot disease of Chinese cabbage caused by Plasmodiophora brassicae. Soil Biol Biochem 32: $1637-1642$

Murakami H, Tsushima S, Akimoto T, Shishido Y (2001) Reduction of spore density of Plasmodiophora brassicae in soil by decoy plants. J Gen Plant Pathol 67: 85-88.

Nasrollahi YK, Kim BH, Jung G (2009) Antifungal activity of silver nanoparticles on some fungi. Plant Dis 93: 1037-1043.

Pulit J, Banach M, Szczygłowska R, Bryk M (2013) Nanosilver against fungi. Silver nanoparticles as an effective biocidal factor. Acta Biochim Po 60: 795-798

Samuel G, Garrett SD (1945) The infected root-hair count for estimating the activity of Plasmodiophora brassicae Woron in the soil. Ann Appl Biol 32: 96-101.

Sarkar S, Jana AD, Samanta SK, Mostafa G (2007) Facile synthesis of silver nano particles with highly efficient antimicrobial property. Polyhedron 26: 4419-4426.

Sharma K, Gossen BD, McDonald MR (2011) Effect of temperature on cortical infection by Plasmodiophora brassicae and clubroot severity. Phytopathology 101: 1424-32.

Siemens J, Bulman S, Rehn F, Sundelin T (2009) Molecular biology of Plasmodiophora brassicae. J Plant Growth Regul 28: 245-251.

Silver S, Phung LT, Silver G (2006) Silver as biocides in burn and wound dressings and bacterial resistance to silver compounds. J Ind Microbiol Biotechnol 33: 627-634. 
Stampoulis D, Sinha SK, White JC (2009) Assaydependent phytotoxicity of nanoparticles to plants. Environ Sci Technol 43: 9473-9479.

Suzuki K, Matsumiya E, Ueno Y, Mizutani J (1992) Some properties of germination - stimulating factor from plants for resting spores of Plasmodiophora brassicae. Ann Phytopathol Soc of Japan 58: 699-705.

Takahashi K (1991) Correlation between fluorescent in resting staining spores reaction and germination Plasmodiophora brassicae. Ann Phytopath Soc Japan 57: 160-164.

Taylor P, Murakami H, Tsushima S, Kuroyanagi Y, Shishido Y (2002) Soil science and plant nutrition reduction of resting spore density of Plasmodiophora brassicae and clubroot disease severity by liming reduction of resting spore density of Plasmodiophora brassicae and clubroot disease severity by liming. Soil Sci Plant Nutr 48: 685-691.

Tremblay N, Bélec C, Laurence H, Carisse O (1999) Clubroot of crucifers: Control strategies. Agric Agri-Food Canada Saint-Jean-sur Richelieu 1-3.

Yin L, Colman BP, McGill BM, Wright JP, Bernhardt ES (2012) Effects of silver nanoparticle exposure on germination and early growth of eleven wetland plants. PLoS One 7, e47674.

Zea L, Salama HMH (2012). Effects of silver nanoparticles in some crop plants, common bean ( Phaseolus vulgaris L .) and corn. Int Res J Biotechnol 3: 190-197.

\title{
SỬ DỤNG NANO BAC CHẾ TẠO TÙ PHƯƠNG PHÁP CHIẾU XẠ NHẰM KHỐNG CHẾ BÊEH SU'NG RẼ̃ GÂY RA BỞI NẤM PLASMODIOPHORA BRASSICAE TRÊN CÂY BẮP CẢI
}

\author{
Lê Thị Anh Tú ${ }^{1}$ Phạm Thị Lệ Hà \\ ${ }^{1}$ Trưòng Đại học Đà Lạt, Lâm Đồng, Việt Nam \\ ${ }^{2}$ Viện Nghiên cưu hạt nhân, Lâm Đồng, Việt Nam
}

\section{TÓM TẮT}

Plasmodiophora brassicae - một trong những nguyên nhân gây bệnh sưng rễ phổ biến trên cây bắp cải. Loại nấm này xâm nhiễm thông qua rễ, gây ra hiện tượng sưng và biến dạng rễ. Do đó, cây khó hấp thu nước và chất dinh dưỡng. Có nhiều phương pháp được sử dụng để khống chế bệnh sưng rễ như: khử trùng đất, điều chỉnh $\mathrm{pH}$ đất, dùng thuốc giệt nấm, bón vôi, chất hoạt động bề mặt. $P$. brassicae được phân lập, xác định và tái nhiễm thành công trên cây bắp cải. Tỷ lệ rễ nhiễm bệnh và tỷ lệ sưng rễ phụ thuộc vào mật độ bào tử nghỉ và môi trường trồng cây - Mật độ bào tử tăng kéo theo sự gia tăng của các hiện tượng nhiễm bệnh trên cây. Hiện nay nano bạc được sử dụng rộng rãi như một chất trừ nấm. Khả năng diệt nấm của vật liệu nano bạc phụ thuộc vào kích thước, hình dạng, và các gốc chức năng trên bề mặt vật liệu. Phương pháp chiếu xạ tia $\gamma$ để chế tạo nano bạc được xem là phương pháp có thể điều khiển kích thước, hình dạng và độ phân tán của vật liệu. Sử dụng vật liệu nano bạc được tổng hợp bằng phương pháp này để khống chế bệnh sưng rễ do nấm $P$. brassicae được điều tra trong nghiên cứu này. Đường kính trung bình của vật liệu nano bạc được chế tạo bằng phương pháp chiếu xạ $\gamma$ sử dụng trong nghiên cứu là $9,5 \mathrm{~nm}$. Trong hai mồi trường trồng cây là môi trường thủy canh và môi trường đất, vật liệu nano bạc thể hiện khả năng ức chế nấm $P$. brassicae. Hiệu quả kháng nấm của vật liệu nano bạc phụ thuộc vào nồng độ và môi trường trồng cây. Không thấy biểu hiện bệnh ở cây trồng trên môi trường thuỷ canh bổ sung $1,06 \mathrm{ppm}$ nano bạc, và cây trồng trên môi trường đất bổ sung 10 và $20 \mathrm{ppm}$ nano bạc. Kết quả của nghiên cứu còn cho thấy sinh khối và chiều cao của cây bệnh thấp hơn rất nhiều so với cây khỏe. Trong khi đó, sinh khối và chiều cao của cây được trồng trên môi trường có bổ sung 10 và 20 ppm nano bạc thu được tương đương với cây khoẻ không bị nhiễm bệnh.

Từ khoá: Bệnh sung rễ cây bắp cải, chiều cao, nano bạc, Plasmodiophora brassicae, sinh khối, tính kháng nấm 